\title{
Algal Community Structure in a Littoral Zone in the North Basin of Lake Biwa
}

\author{
Kentaro NozAKI
}

\begin{abstract}
Seasonal variations in the biomass and species composition of benthic and planktonic algal communities were investigated from June 1994 to April 1996 in a littoral zone with gravel in the north basin of Lake Biwa. Seasonal fluctuations in biomass were mainly brought about by the rise and fall of a filamentous green alga (FGA) Spirogyra sp. in the benthic algal community, together with Closterium aciculare, Staurastrum dorsidentiferum and Gomphosphaeria lacustris in the planktonic algal community. Comparing the benthic with the planktonic algal biomass, the former made up over $90 \%$ of the total algal biomass. This result suggests that the benthic algal community contributes highly to primary production in the littoral zone. There were extraordinary differences in the vertical-distribution pattern and lightextinction coefficient between the FGA and sessile algae (benthic algae except FGA) forming the benthic algal community, thus dividing it into two components: FGA, and sessile algal communities. From the viewpoint of the productive structure of the algal community in the littoral zone, we propose that the community should be regarded as a three-component structure of planktonic, FGA, and sessile algal communities.
\end{abstract}

Key words : filamentous green algae (FGA), littoral zone of lake, productive structure, three-component structure of algal community

\section{INTRODUCTION}

Planktonic algae, benthic algae and macrophytes play an important role as primary producers in aquatic ecosystems. The littoral zone in lakes where more than $1 \%$ of surface light intensity reaches bottom is characterized by the development of a benthic algal community and macrophytes (Moss, 1988). Thus, in order to understand the productive structure in the littoral zone, not only the planktonic algal community but also the benthic algal community and/or macrophytes should be investigated together. However, most algal studies of the littoral zone have been mainly focussed on the benthic algal community (CATTANeo, 1987 ; MEUlemans, 1988 ; Burkholder and WeTzel, 1989 ; Jonsson, 1992 ; Müller, 1994 ; HaWEs and SchWARTz, 1996). On the other hand, there have only been a few investigations of both 
planktonic and benthic algal communities or macrophytes (NAKANISHI et al., 1989 ; TAKamura et al., 1990 ; Steinman et al., 1997).

The development of a filamentous green algal (FGA) community dominated by Spirogyra sp. has been observed in the littoral zone of Lake Biwa since 1983 (WATANABE et al., unpublished data). Occurrence of the FGA community has been observed also in some lakes located in the north temperate region since the 1980s. FGA propagation has been studied as a biological indicator related to changes in lake environments (LORENZ and HERDENDORF, 1982 ; PiECZYŃSKa et al., 1988; TURNER et al., 1995a). However, the ecological effects of FGA intrusion on a littoral-zone ecosystem have been little studied (TURNER et al., 1995b; NozAKI et al., 1998).

In the present study, some characteristics of the algal community structure consisting of benthic and planktonic algae are discussed on the basis of seasonal variations in biomass and species composition of both communities in a littoral zone with gravel in the north basin of Lake Biwa, especially focussing on the intrusion of the FGA.

\section{METHODS}

\section{Study site}

Lake Biwa is divided into 2 basins : the north basin is $618 \mathrm{~km}^{2}$ in surface area, $45 \mathrm{~m}$ in mean depth (maximum : $104 \mathrm{~m}$ ) and mesotrophic; and the south basin is $57 \mathrm{~km}^{2}, 3.5 \mathrm{~m}$ (maximum : $7.6 \mathrm{~m}$ ) and eutrophic. This study was carried out in a littoral zone located at Kita-komatsu in the western part of the north basin (Fig. 1). The survey was conducted biweekly from June 1994 to April 1996. The bottom of the littoral zone was covered with gravel (diameter, 10-20 cm). Macrophytes were not present. Three sampling stations were placed on a transect in an offshore direction (Fig. 1). The depth of each station changed generally together with changes in the water level of Lake Biwa during the investigation period : 10-170 cm (mean 50

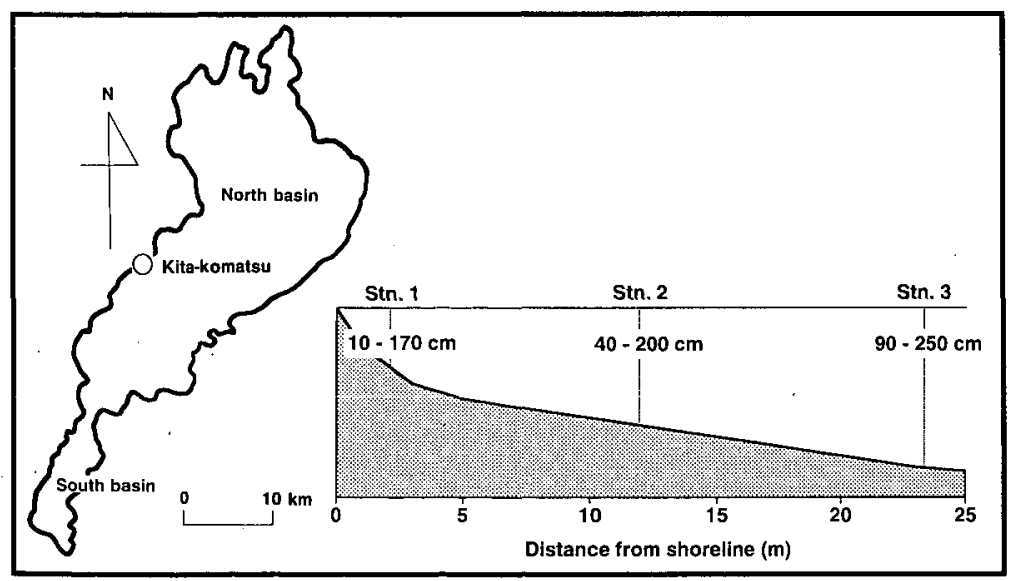

Fig. 1. Location of study site and sampling stations. 
$\mathrm{cm}$ ) at Stn. 1, 40-200 cm (mean $100 \mathrm{~cm}$ ) at Stn. 2 and 90-250 cm (mean $150 \mathrm{~cm}$ ) at Stn. 3. The lowest depths were recorded from June to September 1994, due to an unusual drought (HoRI et al., 1996).

\section{Algal samples}

Three samples of benthic algae from stones in quadrates $(25 \mathrm{~cm} \times 25 \mathrm{~cm})$ were collected at each station by SCUBA diving. The algae were completely removed from the stones using a steel brush. On 13 July 1995 and 29 March 1996 at Stn. 2, the thickness of the benthic algal community was measured with a ruler. Planktonic algal samples were collected at a $5 \mathrm{~cm}$ depth at $\mathrm{Stn}$. 3. All the samples kept in an ice box were carried to the laboratory within $3 \mathrm{~h}$. An aliquot of each sample was filtered on a fibre glass filter (Whatman $\mathrm{GF} / \mathrm{C}$, burned at $450^{\circ} \mathrm{C}$ for $2 \mathrm{~h}$ ) for a determination of chlorophyll $a$ (LORENZEN, 1967). Benthic algal samples were preserved in a $5 \%$ concentration of neutral formalin. Planktonic algae in water samples (1 litre) were fixed with neutral formalin at a final concentration of $5 \%$, and concentrated to $10 \mathrm{ml}$. Identifications of algae were referred to descriptions by HIROSE and YAMAGishi (1977) and WATANABE and Houki (1988). Algal cells were counted under a microscope using a plankton counting chamber (Matsunami S6117, square size $1 \mathrm{~mm} \times 1 \mathrm{~mm}$, volume $1 \mathrm{ml}$ ). Since algae differ greatly in size, cell numbers do not give a true picture of the actual biomass. To evaluate the algal biomass, cell volumes of each alga were calculated by the geometrical cube method (FindeneGG, 1969; Clarke et al., 1987). The volume can be calculated from the dimensions of the cell, assuming that its form corresponds roughly to simple geometrical solids : Sphere $=\left(4 \pi \mathbf{r}^{3}\right) / 3$, Cone $=\left(\pi r^{2} h\right) / 3$, Cylinder $=\pi r^{2} h$, etc. Cell volumes of complex algae are calculated by a combination of some simple geometrical solids (ex. Ceratium, Staurastrum). Cell size was measured randomly using the samples collected during the investigation period. Algal cell numbers of each sample were converted to biovolumes using the mean-cell volumes of each alga (Table 1). Relations between chlorophyll $a$ (benthic algae : $\mathrm{mg} \mathrm{m}^{-2}$, planktonic algae : $\mathrm{mg} \mathrm{m} \mathrm{m}^{-3}$ ) and biovolume (benthic algae : $10^{3} \mathrm{~mm}^{3} \mathrm{~m}^{-2}$, planktonic algae : $10^{3}$ $\mathrm{mm}^{3} \mathrm{~m}^{-3}$ ) of algal communities were shown in Figure 2. Benthic algal chlorophyll $a$ was divided into two fractions of FGA and sessile algae (benthic algae except FGA) using the relation in Figure 2, because of differences in the extinction coefficients of the respective communities as described later.

\section{Environmental conditions}

Water temperature at each station was measured with a thermometer at noon. Underwater light intensity was measured vertically at $20-\mathrm{cm}$ intervals with an underwater quantameter (LI-COR, LI-1000) at Stn. 3 at noon. Light attenuation in the benthic algal community was measured as follows ; benthic algal samples with several different concentrations were poured into glass petri dishes. Light transmittances of the respective samples in the glass petri dishes were measured with a quantameter (Biospherical Instru- 
Table 1. Mean biovolume of each alga in this study (col. : volume of colony, $100 \mu \mathrm{m}$ : volume of $100 \mu \mathrm{m}$ length).

\begin{tabular}{|c|c|c|c|c|c|}
\hline Taxon & $\begin{array}{c}\text { Mean (SD) } \\
\left(\mu \mathrm{m}^{3}\right)\end{array}$ & $n$ & Taxon & $\begin{array}{c}\text { Mean (SD) } \\
\left(\mu \mathrm{m}^{3}\right)\end{array}$ & $n$ \\
\hline Bacillariophyceae & & & Dictyosphaerium pulchellum & $50(10)$ & 10 \\
\hline Achnanthes japonica & $36(20)$ & 10 & Elakatothrix gelatinosa & $30(10)$ & 10 \\
\hline A. lanceolata & $89(30)$ & 10 & Eudorina elegans (col.) & $115000(144000)$ & 18 \\
\hline A. minutissima & $38(20)$ & 10 & Gloeocystis gigas & $220(130)$ & 12 \\
\hline Asterionella formosa & $920(290)$ & 24 & Hormidium sp. & $1660(230)$ & 10 \\
\hline Aulacoseira granulata & $6020(3230)$ & 40 & Kirchneriella lunaris & $40(6)$ & 10 \\
\hline A. solida & $1020(520)$ & 10 & Mougeotia sp. & $4430(9000)$ & 86 \\
\hline Ceratoneis arcus & $470(140)$ & 10 & Oedogonium sp. 1 & $20400(19000)$ & 72 \\
\hline Cocconeis placentula & $770(320)$ & 15 & Oedogonium sp. 2 & $244000(98000)$ & 25 \\
\hline Cyclotella comta & $110(60)$ & 15 & Oocystis spp. (col.) & $1840(220)$ & 10 \\
\hline C. meneghiniana & $105(60)$ & 14 & Pediastrum simplex (col.) & $12400(7000)$ & 10 \\
\hline Cymbella cistula & $6440(5600)$ & 10 & P. tetras (col.) & $1300(580)$ & 10 \\
\hline C. minuta & $1220(730)$ & 10 & Quadrigula chodatii & $1840(100)$ & 10 \\
\hline C. tumida & $12600(12600)$ & 10 & Schroederia setigera & $190(100)$ & 10 \\
\hline Denticula kuetzingii & $7450(3230)$ & 10 & Scenedesmus acuminatus & $19(6)$ & 10 \\
\hline Diatoma hiemale & $990(360)$ & 10 & S. denticulatus & $120(10)$ & 10 \\
\hline D. vulgare & $5320(1960)$ & 10 & S. ecornis & $50(10)$ & 10 \\
\hline Epithemia spp. & $11370(9700)$ & 10 & S. quadricauda & $160(20)$ & 10 \\
\hline Fragilaria capucina & $470(140)$ & 214 & Scenedesmus sp. & $10\langle 1\rangle$ & 10 \\
\hline$F$. construens & $250(240)$ & 24 & Sphaerocystis schroeteri & $70(30)$ & 10 \\
\hline F. crotonensis & $760(260)$ & 14 & Spirogyra sp. & $388000(181000)$ & 210 \\
\hline$F$. virescens & $430(130)$ & 10 & Stigeoclonium lubricum $(100 \mu \mathrm{m}$ & m) $5200(2100)$ & 51 \\
\hline Gomphonema olivaceum & $160(100)$ & 22 & Staurastrum arctiscon & $44000(21500)$ & 10 \\
\hline G. paruvulum & $110(80)$ & 10 & S. dorsidentiferum & $24300(6000)$ & 14 \\
\hline G. tetrastigmatum & $780(580)$ & 14 & Xanthidium antilopaeum & $80500(12000)$ & 10 \\
\hline Melosira varians & $7060\langle 940)$ & 10 & Ulothrix zonata $(100 \mu \mathrm{m})$ & $35000(25000)$ & 100 \\
\hline Navicula cryptocephala & $320(190)$ & 44 & & & \\
\hline Navicula lanceolata & $1070(420)$ & 34 & Cyanophyceae & & \\
\hline N. viridula & $1300(360)$ & 19 & Aphanothece clathrata (col.) & $13000(1200)$ & 10 \\
\hline Nitzschia acicularis & $200(80)$ & 10 & Chroococcus sp. & $3(1)$ & 10 \\
\hline N. actinastroides & $290(100)$ & 24 & Gomphosphaeria lacustris (col.) & $14100(11100)$ & 180 \\
\hline N. dissipata & $110(70)$ & 35 & Homoeothrix janthina $(100 \mu \mathrm{m})$ & $2830(110)$ & 10 \\
\hline N. paleacea & $260(80)$ & 16 & Lyngbya martensiana $(100 \mu \mathrm{m})$ & $5430(210)$ & 10 \\
\hline Pinnularia gibba & $8190(5490)$ & 10 & Lyngbya sp. $(100 \mu \mathrm{m})$ & $340(40)$ & 10 \\
\hline Rhoicosphenia curvata & $1630(1630)$ & 10 & Oscillatoria sp. $1(100 \mu \mathrm{m})$ & $8500(1100)$ & 10 \\
\hline Stephanodiscus carconensis (winter & r) $6150(4530)$ & 44 & Oscillatoria sp. $2(100 \mu \mathrm{m})$ & $1360(50)$ & 10 \\
\hline S. carconensis (spring-autumn) & $770(520)$ & 40 & Phormidium tenue & $30(10)$ & 10 \\
\hline Synedra acus & $1240(320)$ & 15 & Phormidium sp. $(100 \mu \mathrm{m})$ & $530(60)$ & 10 \\
\hline S. rumpense & $470(60)$ & 18 & & & \\
\hline \multirow[t]{2}{*}{ S. ulna } & $1660(950)$ & 41 & Cryptophyceae & & \\
\hline & & & Cryptomonas ovata & $8000(1250)$ & 10 \\
\hline \multicolumn{6}{|l|}{ Chlorophyceae } \\
\hline Actinastrum hantzschii & $130(90)$ & 10 & Dinophyceae & & \\
\hline Ankistrodesmus falcatus var. $m$ & mirabilis $11(7)$ & 40 & Ceratium hirundinella & $53000(32300)$ & 10 \\
\hline Chlamydomonas spp. & $300(200)$ & 14 & Glenodinium sp. & $320(170)$ & 10 \\
\hline Cladophora glomerata & $698000(918000)$ & 100 & Gymnodinium sp. & $2960(1600)$ & 10 \\
\hline Closterium aciculare & $10700(3600)$ & 51 & Peridinium sp. & $3160(1920)$ & 10 \\
\hline C. aciculare var. variavile & $1740(510)$ & 10 & & & \\
\hline Coelastrum cambricum (col.) & $4320(3100)$ & 14 & Euglenophyceae & & \\
\hline Cosmarium sp. & $290(40)$ & 10 & Trachelomonas spp. & $13000(8000)$ & 12 \\
\hline
\end{tabular}



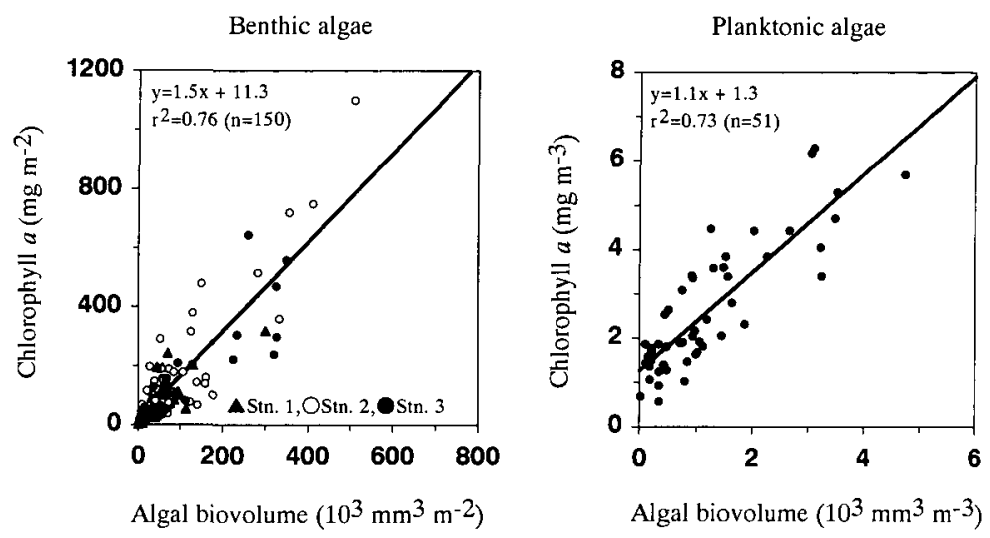

Fig. 2. Relationships between bivolume and chlorophyll $a$ of benthic (left) and planktonic (right) algae.

ment, QSL-100) under artificial light (Toshiba reflector lamp $500 \mathrm{~W}$ ). The light transmittance was related to the algal community thickness expressed as chlorophyll $a\left(\mathrm{mg} \mathrm{m}^{-2}\right)$ determined by the method of LORENZEN (1967).

The extinction coefficient in water or in a benthic algal community was given by the following formula,

$$
I=I_{0} \exp ^{-k z}
$$

$I_{0}$ : photon flux density on surface water or on the top of the benthic algal community $\left(\mu \mathrm{E} \mathrm{m}^{-2} \mathrm{~s}^{-1}\right)$

$k$ : extinction coefficient in water or in the benthic algal community $\left(\mathrm{m}^{-1}\right.$ or $\mathrm{mg}$ chl. $\left.a^{-1}\right)$

$\mathrm{z}$ : depth $(\mathrm{m})$ or chlorophyll $a\left(\mathrm{mg} \mathrm{m}^{-2}\right)$.

Assuming that the chlorophyll $a$ contents per unit algal cell were the same, light attenuation in the benthic algal community would be estimated using the extinction coefficient and chlorophyll $a$.

Water samples for analyses of nutrients were collected from two layers : $5 \mathrm{~cm}$ below the surface, and just above the bottom at each station. Filtrate through fibre glass filters (Whatman $\mathrm{GF} / \mathrm{C}$, burned at $450{ }^{\circ} \mathrm{C}$ for $2 \mathrm{~h}$ ) was used for dissolved inorganic nitrogen compounds (DIN), and those through a fibre glass filter acidified with $0.1 \mathrm{~N} \mathrm{HCl}$ were used for the analysis of $\mathrm{PO}_{4}{ }^{3-}-\mathrm{P}$. Nutrients analyzed were as follows $; \mathrm{NH}_{4}{ }^{+}-\mathrm{N}$ (Solorzano, 1969), $\mathrm{NO}_{2}{ }^{-}-\mathrm{N}$ (Bendschneider and RoBinson, 1952), $\mathrm{NO}_{3}{ }^{-}-\mathrm{N}$ (KALFF and Bent. ZEN, 1984), and $\mathrm{PO}_{4}{ }^{3-}-\mathrm{P}$ (MURPHY and RILEY, 1962).

\section{RESULTS}

\section{Physico-chemical variables}

Water temperature at each station varied seasonally from $6.1^{\circ} \mathrm{C}$ on 28 February 1996 to $32.6{ }^{\circ} \mathrm{C}$ on 24 August 1995 (Fig. 3a). There was no 

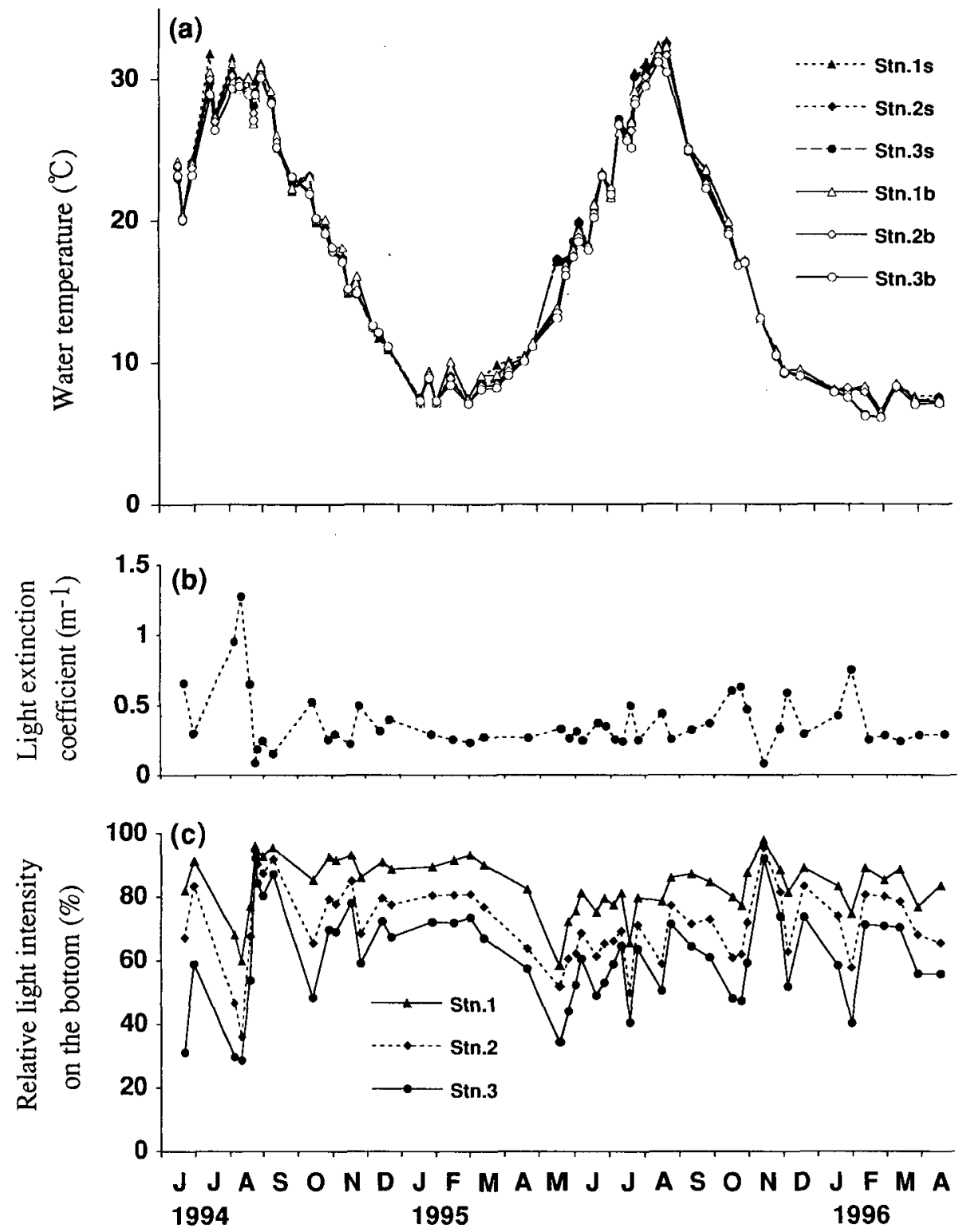

Fig. 3. Seasonal changes in water temperature (a) (s : surface, b: bottom), lightextinction coefficient in water at Stn. 3 (b), and relative light intensity reaching the top of benthic algal community (c).

significant difference in water temperature among the stations or between the surface and bottom. The light-extinction coefficients in water varied from $0.083 \mathrm{~m}^{-1}$ to $1.275 \mathrm{~m}^{-1}$ (Fig. $3 \mathrm{~b}$ ), being not so different from those of previous reports on the pelagic zone of the north basin $\left(0.25-1.31 \mathrm{~m}^{-1}\right.$, NAKANISHI, $1976 ; 0.276-0.767 \mathrm{~m}^{-1}$, NAKANISHI et al., 1992), though the range was greater than that in the pelagic zone. Relative light intensities just 
above the benthic algal community calculated using the extinction coefficients in water were $58-98 \%, 36-95 \%$ and $29-92 \%$ of the surface light intensity at Stns. 1, 2 and 3, respectively (Fig. 3c). Thus, the light seemed to be sufficient for the development of the benthic algal community at all stations (STRICKLAND, 1958).

Figure 4 shows seasonal changes in $\mathrm{DIN}\left(\mathrm{NH}_{4}{ }^{+}-\mathrm{N}, \mathrm{NO}_{2}{ }^{-}-\mathrm{N}\right.$ and $\left.\mathrm{NO}_{3}{ }^{-}{ }^{-} \mathrm{N}\right)$
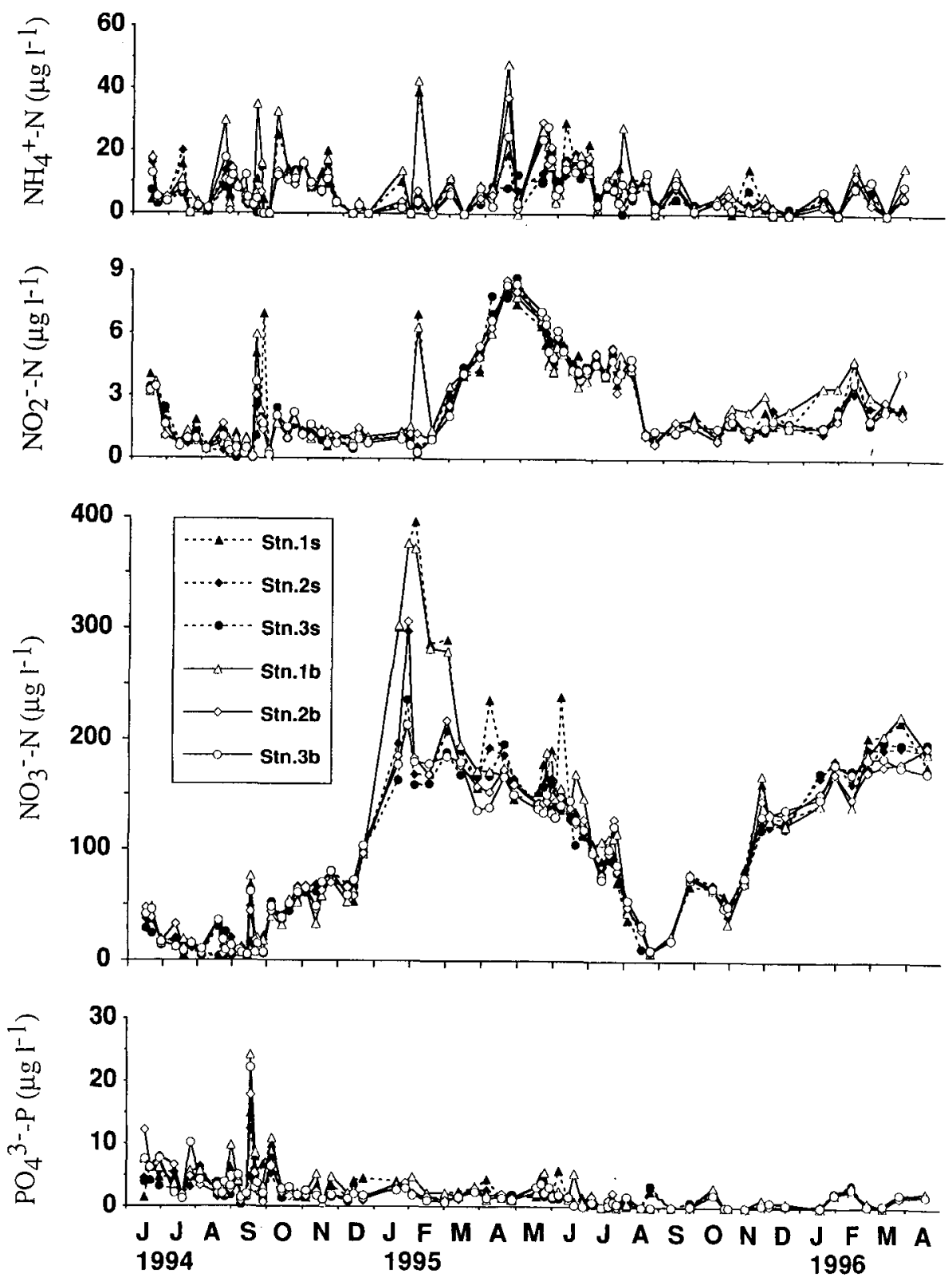

Fig. 4 Seaconal changes in concentrations of DIN $\left(\mathrm{NH}_{4}{ }^{-} \mathrm{N}, \mathrm{NO}_{2}{ }^{-}-\mathrm{N}\right.$ and $\left.\mathrm{NO}_{3}{ }^{-}-\mathrm{N}\right)$ and DIP $\left(\mathrm{PO}_{4}{ }^{3-}-\mathrm{P}\right)$ in surface ( $\mathrm{s}$ ) and bottom (b) layers at each station. 
and DIP $\left(\mathrm{PO}_{4}{ }^{3-}-\mathrm{P}\right)$ concentrations of the surface and bottom layers at all stations. DIN and DIP concentrations were not very different among the stations or between the surface and bottom, varying within a range of 0-48 $\mu \mathrm{g} \mathrm{l}^{-1}$ in $\mathrm{NH}_{4}{ }^{+}-\mathrm{N}, 0-9 \mu \mathrm{g} \mathrm{l}^{-1}$ in $\mathrm{NO}_{2}{ }^{-}-\mathrm{N}, 4-396 \mu \mathrm{g} \mathrm{l}^{-1}$ in $\mathrm{NO}_{3}{ }^{-}-\mathrm{N}$, and $0-24$ $\mu \mathrm{g} \mathrm{l}^{-1}$ in $\mathrm{PO}_{4}{ }^{3-}-\mathrm{P}$. Since concentrations of $\mathrm{NH}_{4}{ }^{+} \mathrm{N}$ and $\mathrm{NO}_{2}{ }^{-} \mathrm{N}$ were usually far lower than that of $\mathrm{NO}_{3}{ }^{-}-\mathrm{N}$, the total DIN concentration changed seasonally depending on the concentration of $\mathrm{NO}_{3}{ }^{-}-\mathrm{N}$ at all stations. The seasonal pattern and concentration of DIN were similar to those of the offshore surface in the north basin (TEzUKA, 1984). The varying range of $\mathrm{PO}_{4}{ }^{3-}-\mathrm{P}$ concentration was also similar to that in the pelagic zone.

These results suggest that water temperature as well as light and nutrient conditions in the water at this study site were similar to those of previous studies in the pelagic zone.
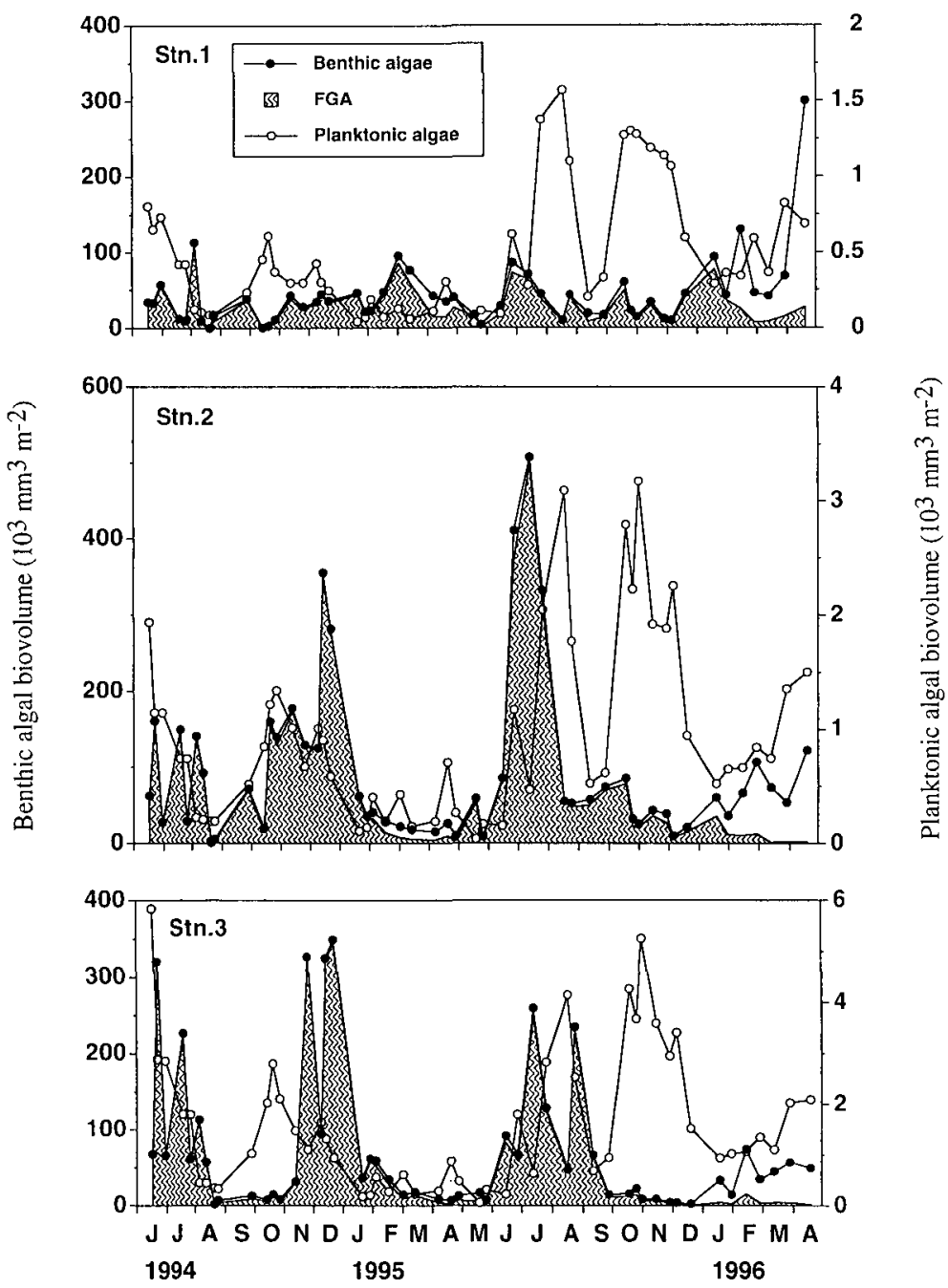

Fig. 5. Seasonal variations in total biovolumes of benthic and planktonic algae at each station (shaded area; filamentous green algae). 

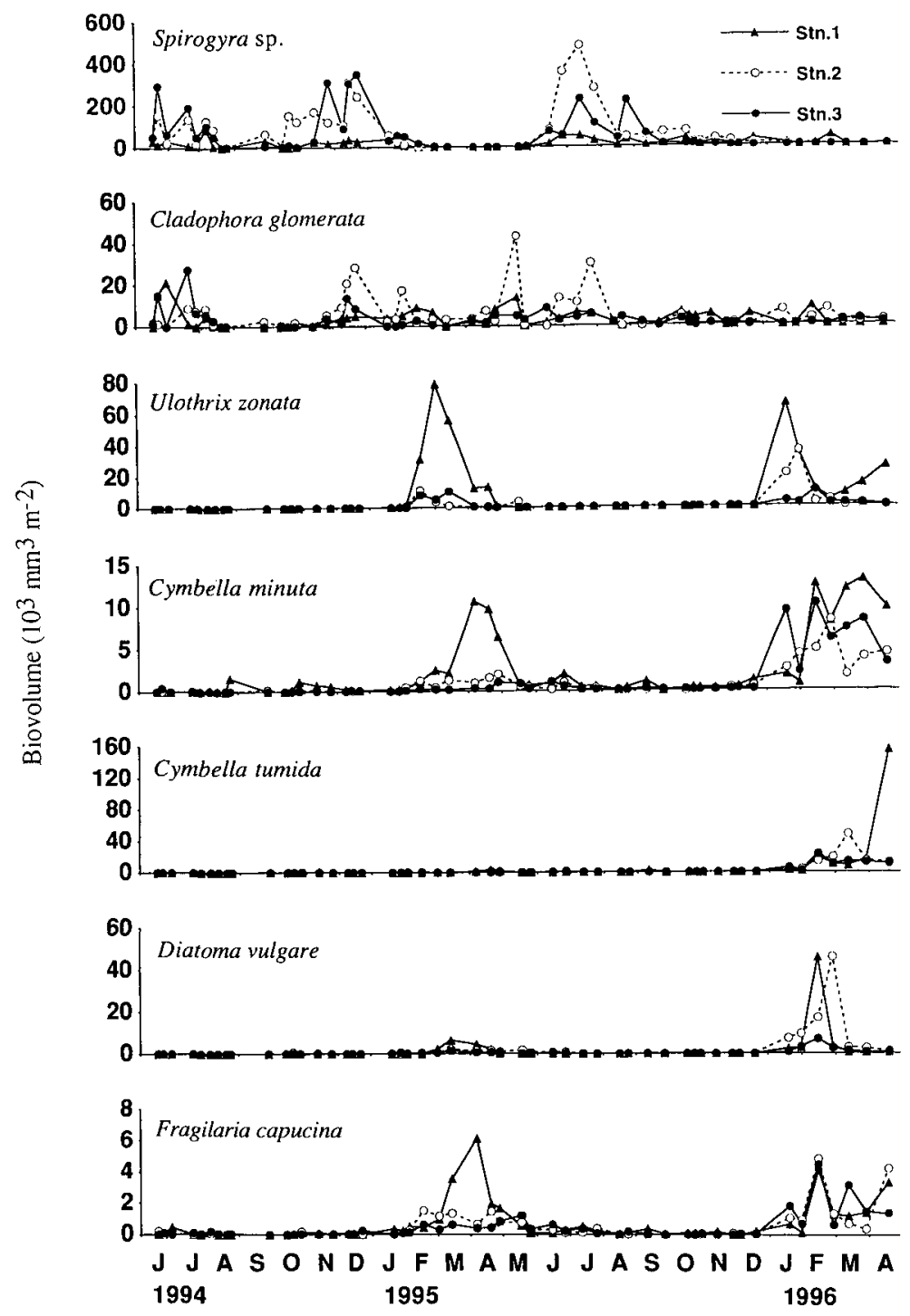

Fig. 6. Seasonal variations in biovolumes of predominant species of benthic algae at each station.

\section{Seasonal variations of algal communities}

The biomass of benthic and planktonic algal communities (expressed as biovolume) varied from station to station, though seasonal patterns of biomass and species composition of both communities were not so different among stations throughout the investigation period. It was characterized that peaks in the biomass of benthic and planktonic algal communities were formed by a drastic propagation by 1 or 2 species.

The biomass of the benthic algal community varied seasonally with three peaks formed in June-July 1994, November-December 1994 and June-July 1995 except for Stn. 1 (Fig. 5). The biomass ranged from 0.13 to $300 \times 10^{3}$, 

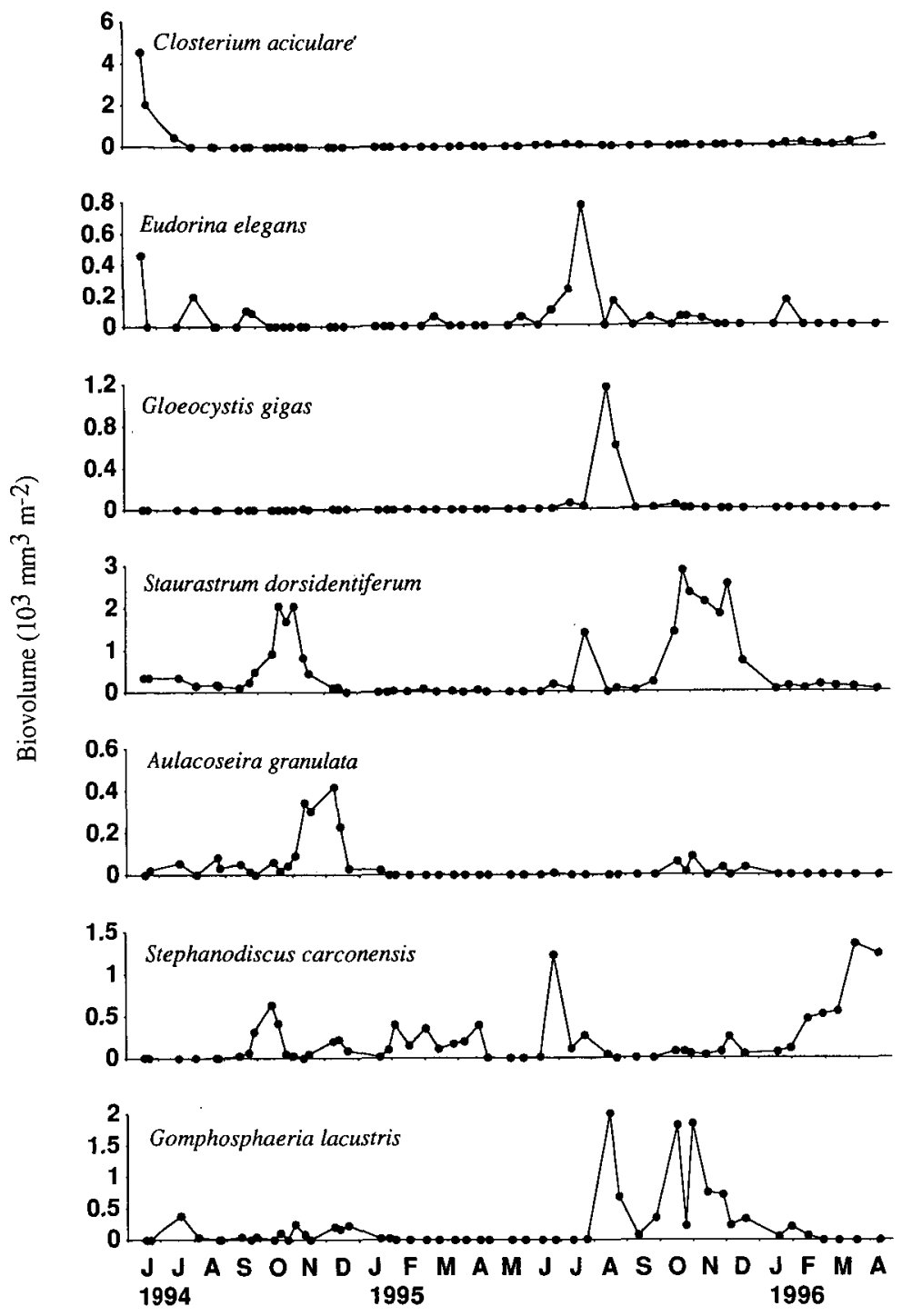

Fig. 7. Seasonal variations in biovolumes of predominant species of planktonic algae at Stn. 3.

$0.87-508 \times 10^{3}$ and $1.55-349 \times 10^{3} \mathrm{~mm}^{3} \mathrm{~m}^{-2}$ at Stns. 1,2 and 3, respectively. These peaks were brought about by the propagation of large FGA such as Spirogyra sp. and Cladophora glomerata. A small peak observed in January-April 1996 at all stations was formed by the small FGA Ulothrix zonata and by the sessile algae Cymbella minuta, Cymbella tumida, Diatoma vulgare and Fragilaria capucina (Fig. 6).

The total biomass of the planktonic algal community was $0.03-1.6 \times 10^{3}$, $0.04-3.2 \times 10^{3}$ and $0.06-5.8 \times 10^{3} \mathrm{~mm}^{3} \mathrm{~m}^{-2}$ at Stns. 1,2 and 3, respectively (Fig. 5). The biomass of the planktonic algal community showed five peaks in the seasonal change, $i$. e., by the propagation of Closterium 
aciculare in June 1994, Staurastrum dorsidentiferum in October-December 1994, Gomphosphaeria lacustris in July-August 1995, and G. lacustris, and S. dorsidentiferum in October-December 1995 ; and Stephanodiscus carconensis in March-April 1996 (Fig. 7). Dominant species in the planktonic algal community were similar to those in previous studies of the pelagic zone in the north basin (NAKANishi, 1976 ; Tezuka, 1984 ; TezUKa and NAKANISHI, 1991). Thus, the planktonic algal community at this study site seemed to reflect that of the pelagic zone. In fact, abiotic factors controlling the algal growth such as water temperature, light and nutrient concentrations were not very different from those of the pelagic zone.

The seasonally changing pattern of benthic algal biomass seemed to quite similar to that of the planktonic algal pattern except for October-December 1996 when a planktonic algal peak was formed by the propagation of $G$. lacustris and $S$. dorsidentiferum. The benthic algal biomass occupied more than $90 \%$ of the total algal biomass, and the contribution of FGA to the benthic algal biomass was more than $70 \%$ (Table 2 ).

Table 2. Variation ranges and mean values of algal biomass at each station.

\begin{tabular}{|c|c|c|c|c|c|c|c|c|}
\hline \multirow[t]{3}{*}{ Site } & \multicolumn{4}{|c|}{ Algal biovolume $\left(10^{3} \mathrm{~mm}^{3} \mathrm{~m}^{-2}\right)$} & \multicolumn{4}{|c|}{ Relative abundance in total algal biovolume (\%) } \\
\hline & \multicolumn{3}{|c|}{ Benthic algae } & \multirow{2}{*}{$\begin{array}{c}\text { Planktonic } \\
\text { algae }\end{array}$} & \multicolumn{3}{|c|}{ Benthic algae } & \multirow{2}{*}{$\begin{array}{l}\text { Planktonic } \\
\text { algae }\end{array}$} \\
\hline & Total & FGA & Sessile algae & & Total & FGA & Sessile algae & \\
\hline \multicolumn{9}{|l|}{ Station 1} \\
\hline Range & $0.13-300.0$ & $0.08-108.4$ & $0.05-272.6$ & $0.03-1.57$ & $42.7-99.9$ & $9.1-95.6$ & $4.3-90.6$ & $0.1-57.3$ \\
\hline Mean & 43.2 & 28.0 & 15.2 & 0.49 & 95.8 & 68.8 & 27.0 & 4.2 \\
\hline \multicolumn{9}{|l|}{ Station 2} \\
\hline Range & $0.87-507.5$ & $0.75-496.6$ & $0.12-119.8$ & $0.04-3.17$ & $80.6^{-99.9}$ & $1.8-99.0$ & $0.4-97.0$ & $0.1-1.94$ \\
\hline Mean & 94.0 & 79.4 & 14.6 & 0.96 & 94.5 & 71.2 & 26.3 & 2.5 \\
\hline \multicolumn{9}{|l|}{ Station 3} \\
\hline Range & $1.55-348.9$ & $0.71-344.5$ & $0.60^{-} 58.5$ & $0.06-5.84$ & $54.1-99.8$ & $3.3-98.5$ & $1.2-92.7$ & $0.2-45.9$ \\
\hline Mean & 71.6 & 62.5 & 9.01 & 1.64 & 91.9 & 63.9 & 28.0 & 8.1 \\
\hline
\end{tabular}

\section{Light attenuation in each algal community}

Light-extinction coefficients in communities of FGA and sessile algae were 0.005 (mg chl. $\left.a^{-1}\right)$ and $0.029\left(\mathrm{mg} \mathrm{chl} . a^{-1}\right)$, respectively (Fig. 8). The extinction coefficient of the sessile algal community was similar to that in the previous studies $\left(0.02 \mathrm{mg}\right.$ chl. $a^{-1}$ by TOMINAGA and ICHIMURA, $1966 ; 0.023$ mg chl. $a^{-1}$ by NaKanishi and Yamamura, 1984). The extinction coefficient of the FGA community was remarkably small compared with that of the sessile algal community. One reason for the extremely low extinction coefficient of the FGA community might be due to their relatively small content of detritus and inorganic matter closely related to light attenuation when compared with those in the sessile algal community. In fact, ignition loss was $60-70 \%$ of the total dry weight in the FGA community, but less than $10 \%$ in the sessile algal community (NozAKI, unpublished data).

The respective attenuations by planktonic, FGA and sessile algal communities were calculated using the extinction coefficients and water depth or 


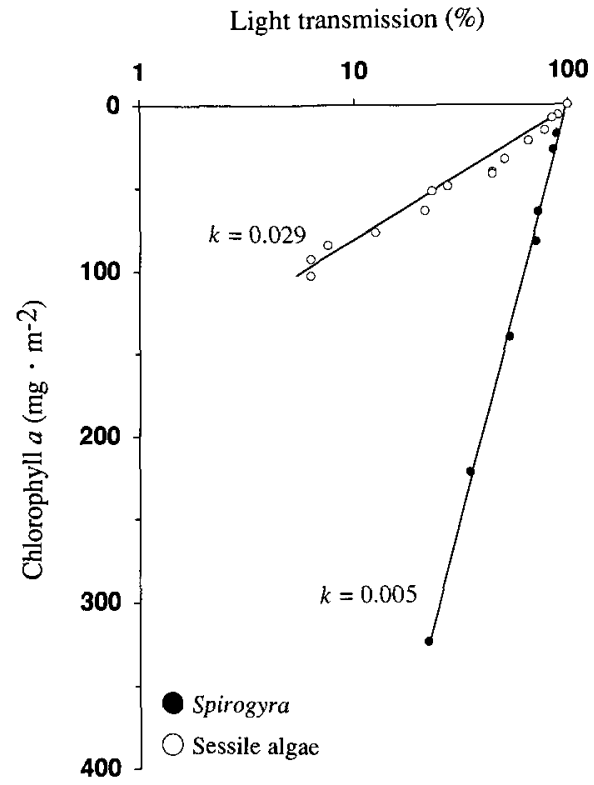

Fig. 8. Relations of light transmittance to chlorophyll $a$ of sessile (open circle, $k=0.029 \mathrm{mg}$ chl. $a^{-1}$ ) and filamentous green alga Spirogyra $\mathrm{sp}$. (solid circle, $k=0.005 \mathrm{mg}$ chl. $a^{-1}$ ) communities.

chlorophyll $a$. Chlorophyll $a$ of the benthic algal community was roughly divided into two fractions of FGA and sessile algae using the relation in Figure 2. Light attenuation in each algal community varied seasonally over ranges of 2-40,5-64 and 8-71\% for planktonic algae, $0.1-55,0.5-77$ and 0. $6-65 \%$ for the FGA, and $0.3-73,0.2-71$ and $0.8-58 \%$ for sessile algae, at Stns. 1, 2 and 3, respectively (Fig. 9). More than $99 \%$ of the surface-light intensity was attenuated by planktonic and FGA communities (Fig. 9) whenever the FGA biomass exceeded $500 \times 10^{3} \mathrm{~mm}^{3} \mathrm{~m}^{-2}$ in biovolume, corresponding to the $800 \mathrm{mg} \mathrm{m}^{-2}$ in chlorophyll $a$ (Figs. 2 and 5). This fact suggests that an increase in FGA strongly depresses the growth of sessile algae by the shading.

\section{DISCUSSION}

\section{Contribution of benthic and planktonic algae as primary producers}

The relative contribution of the benthic algal community to primary production in the littoral zone varies depending on the trophic status of lakes. HANSSON (1988) reported that the contribution of the benthic algal community increases in oligotrophic lakes because of the sparsity of planktonic algal biomass, whereas it decreases in eutrophic lakes due to an increase in planktonic algal biomass. The biomass of benthic algae exceeded $90 \%$ of the total algal biomass at all stations. This suggests that the benthic algal community contributes significantly to primary production in the littoral zone (Table 2). Furthermore, FGA in the benthic algal community, 


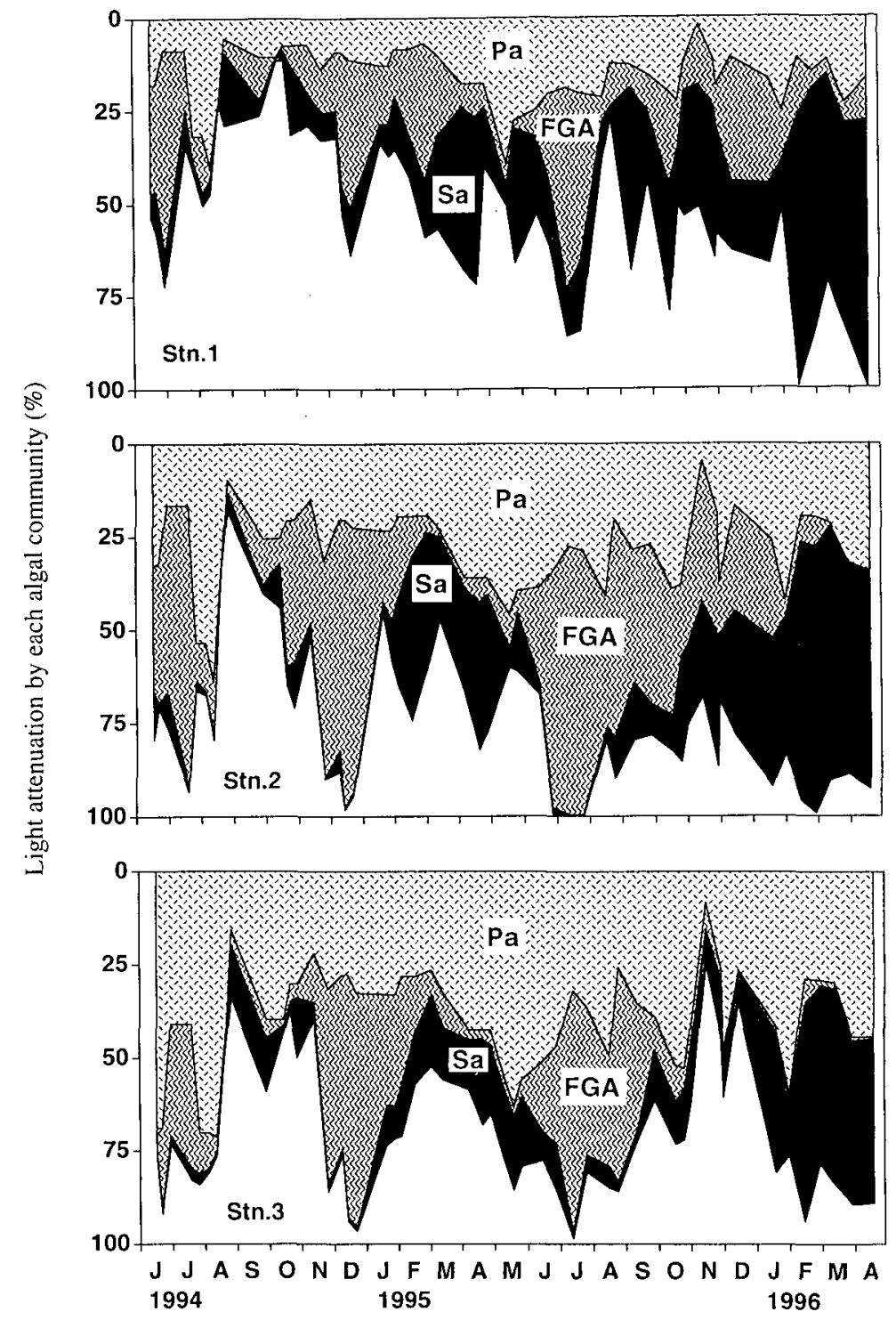

Fig. 9. Light attenuation by each algal community ( $\mathrm{Pa}$ : planktonic algae, FGA : filamentous green algae, $\mathrm{Sa}$ : sessile algae) at each station.

especially Spirogyra sp. with its extraordinarily high biomass, seemed to be the major primary producer (Figs. 5 and 6). TAKAMURA et al. (1990) reported that the photosynthesis of benthic algae was light-limited by shading from the planktonic algal community during the period when chlorophyll $a$ was $100-400 \mathrm{mg} \mathrm{m}^{-3}$ by a bloom of Microcystis in a littoral zone of hypertrophic Lake Kasumigaura. Hansson (1992) also suggested that benthic algal growth was depressed by shading from the planktonic algal community in the littoral zone (depth, $0-75 \mathrm{~cm}$ ) of Swedish lake, when the 
extinction coefficient exceeded $1.5 \mathrm{~m}^{-1}$. In this study, the maximum chlorophyll $a$ and the extinction coefficient in the water were $6 \mathrm{mg} \mathrm{m}^{-3}$ and 1.275 $\mathrm{m}^{-1}$, respectively (Figs. 2 and $3 \mathrm{c}$ ). In comparison with the maximum chlorophyll $a$ and light-extinction coefficient obtained from data of the references, the growth of the benthic algal community at this study site seemed not to be limited by shading from the planktonic algal community.

\section{Effects of intrusion of FGA on the algal community structure}

In the north basin of Lake Biwa, the benthic algal community in the littoral zone consisted only of sessile algae in 1963, and the maximum chlorophyll $a$ was $100 \mathrm{mg} \mathrm{m}^{-2}$ in February (SAIJO et al., 1966). In the present study, the seasonal fluctuation in biomass of the benthic algal community was affected intensely by the rise and fall of Spirogyra. Consequently, the maximum biomass was estimated to be $500 \times 10^{3} \mathrm{~mm}^{3} \mathrm{~m}^{-2}$ in biovolume and $800 \mathrm{mg} \mathrm{m}^{-2}$ in chlorophyll $a$ (Fig. 5, cf. Fig. 2). The intrusion of FGA such as Spirogyra contributed to an increase in the biomass of the benthic algal community and altered the seasonal biomass pattern in the littoral zone.

Figure 10 shows the vertical profiles of algal-community structure and light attenuation at Stn. 2 on 13 July 1995 when the FGA flourished, and on 29 March 1996 when the benthic algal community consisted only of sessile algae. There were clear differences in the vertical distribution of the biomass and the relative light intensity between the two observations. On 13 July 1995, relative light intensity was attenuated to $70 \%$ of the surface light intensity above the FGA community, and decreased to $0.32 \%$ above the sessile algal community through shading from the FGA community. Further,

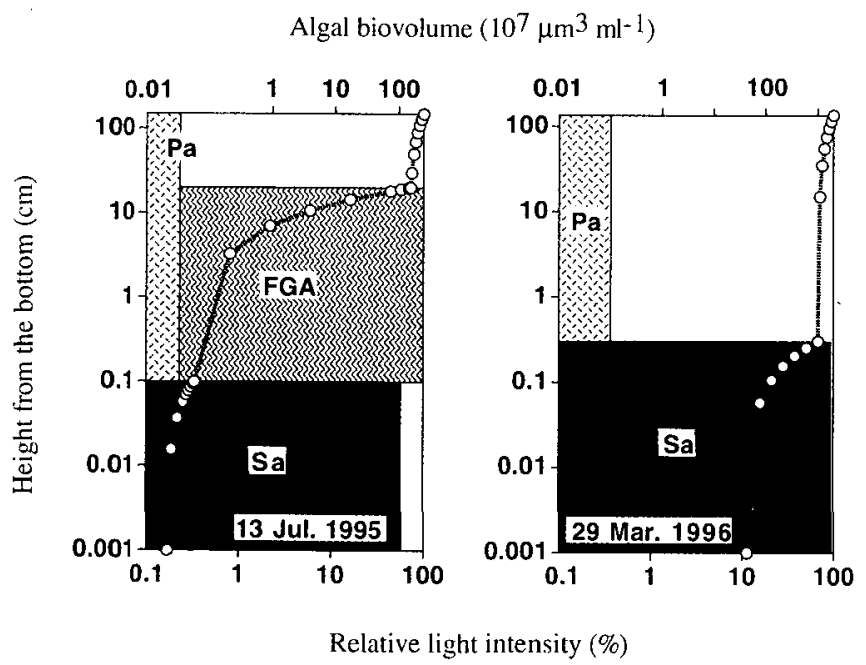

Fig. 10. Comparisons among vertical profiles of algal community structure ( $\mathrm{Pa}$ : planktonic algae, FGA : filamentous green algae, Sa : sessile algae) and light attenuation at Stn. 2 on 13 July 1995 and on 29 March 1996. 
relative light intensity beneath the sessile algal community fell to $0.1 \%$. On 29 March 1996, relative light intensity decreased to $68 \%$ above the sessile algal community and $11 \%$ beneath the sessile algal community. These results suggest that the development of the FGA community in the littoral zone of the lake changed the productive structure of the algal community. Development of the FGA community creates a diversiform structure in the littoral zone of a lake, and may prepare a new habitat for algae attaching to the FGA (Lowe, 1996), whereas the shade created may act negatively on the growth of sessile algae attaching to stones (cf. Fig. 9).

It is well known that a benthic algal community is stronger in its selfshading effect than a planktonic algal community, because the benthic algal cells are densely accumulated in a narrow space (AIZAKI, 1980 ; BosTON and Hill, 1991 ; Hill and Boston, 1991 ; Müller, 1995). In our study, the light-extinction coefficient in the FGA community was extraordinarily low $\left(0.005 \mathrm{mg}\right.$ chl. $\left.a^{-1}\right)$ as compared with that of the sessile algal community $\left(0.029 \mathrm{mg}\right.$ chl. $\left.a^{-1}\right)$. Consequently, the FGA community seemed to be less self-shading than the sessile algal community. Assuming that the light intensity at the compensation point was $1 \%$ of the surface irradiance, the potential chlorophyll $a$ in the productive layer of the benthic algal community alone was estimated as approximately $850 \mathrm{mg} \mathrm{m}^{-2}$ of FGA, and as 150 $\mathrm{mg} \mathrm{m}^{-2}$ of sessile algae alone at Stn. 2 on 13 July 1995 (Fig. 8). After ARUGA (1973), chlorophyll $a$ in the productive layer of a planktonic algal community was below $100 \mathrm{mg} \mathrm{m}^{-2}$ in the sea and oligotrophic lakes and 100 $-1000 \mathrm{mg} \mathrm{m}^{-2}$ in meso- and eutrophic lakes, whereas it reached $200-250 \mathrm{mg}$ $\mathrm{m}^{-2}$ in a sessile algal community in a river (TOMINAGA and ICHIMURA, 1966 ; AizaKI, 1980 ; NAKANISHI and YAMAMURA, 1984) and $900 \mathrm{mg} \mathrm{m}^{-2}$ in a pure culture of Scenedesmus (ARUGA, 1966). The potential chlorophyll $a$ in the productive layer of an FGA community is equivalent to the maximum value in eutrophic lakes and in a pure culture. It is expected that the development of an FGA community contributes to enhance the productivity in the littoral zone of lakes by increasing in the algal biomass.

An algal community in the littoral zone of lakes has been considered as having a two-component structure consisting of planktonic and benthic algal communities. In our case, FGA such as Spirogyra sp. have been included in the benthic algae. However, there were extraordinary differences in the light-extinction coefficient and the vertical-distribution pattern of biomass between the FGA and sessile algal communities (Figs. 8 and 10). Thus, in the littoral zone where an FGA community develops, the benthic algal community should be divided into two components, i. e., FGA and sessile algal communities (Fig. 11). The effect of FGA intrusions into freshwater ecosystems has been mainly described as creating a new habitat for benthic animals (PowER, 1990a, b). In this study, from the viewpoint of the productive structure of an algal community in the littoral zone, we propose that such a community should be regarded as a three-component structure of planktonic, FGA and sessile algal communities. 


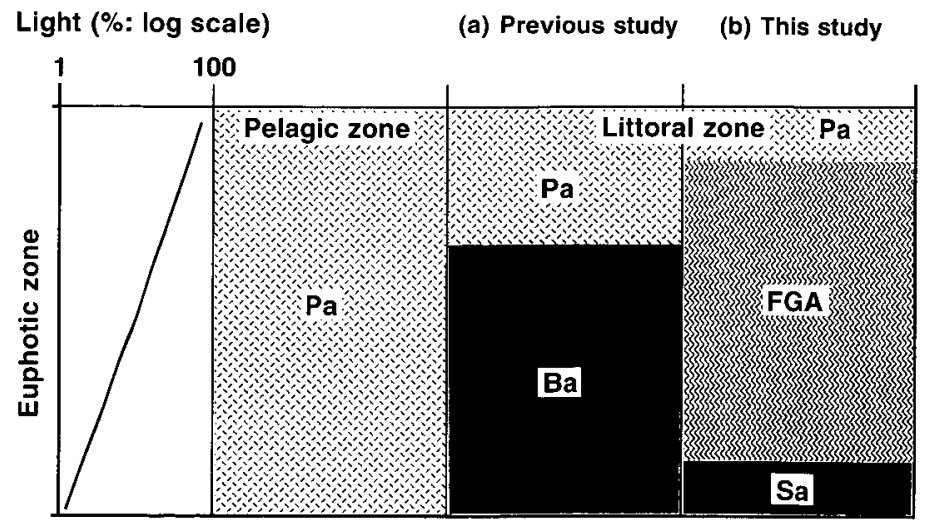

Fig. 11. A schematic picture of algal community structures in the euphotic zone of pelagic and littoral zones ( $\mathrm{Pa}$ : planktonic algae, $\mathrm{Ba}$ : benthic algae, FGA : filamentous green algae, Sa: sessile algae).

\section{ACKNOWLEDGEMENTS}

The author is grateful to Prof. M. NAKANisHI of the Center for Ecological Research, Kyoto University, for his help in this study, especially for his valuable suggestions. Thanks are also due to Captain T. KoITABASH of the Center for Ecological Research, Kyoto University, and Mr. Y. OHNo of the Tajima Fisheries Office, Hyogo Prefecture for their help in the field survey and in the laboratory.

\section{REFERENCES}

AIzAKI, M. (1980) : Changes in standing crop and photosynthetic rate attendant on the film development of periphyton in a shallow eutrophic river. Jpn. J. Limnol., $41: 225-234$ (in Japanese with English abstract).

ARUGA, Y. (1966) : Ecological studies of photosynthesis and matter production of phytoplankton. III. Relationship between chlorophyll amount in water and primary productivity. Bot. Mag. Tokyo, $79: 20-27$.

ARUGA, Y. (1973) : Matter production of aquatic plant community II. Phytoplankton. Kyouritsu shuppan (in Japanese) .

BendSCHNEIDER, K. and R. T. ROBINSON (1952): A new spectrophotometric method for determination of nitrite in sea water. J. Mar. Res., 11: 87-96.

Boston, H. L. and W. R. HILl (1991) : Photosynthesis-light relations of stream periphyton communities. Limnol. Oceanogr., 36 : 644-656.

Burkholder, J. M. and R. G. W. WeTzel (1989) : Epiphytic microalgae on natural substrata in a hardwater lake : seasonal dynamics of community structure, biomass and ATP content. Arch. Hydrobiol./Suppl., 83 : 1-56.

Cattaneo, A. (1987) : Periphyton in lakes of different trophy. Can. J. Fish. Aquat. Sci., $44: 296-303$.

Clarke, R. T., A. H. H. Marker and J. A. Rother (1987) : The estimation of the mean and variance of algal cell volume from critical measurements. Freshwat. Biol., 17 : 117-128. 
FindenegG, I. (1969) : Expressions of populations. In A manual on methods for measuring primary production in aquatic environment, VOLLENWEIDER, $R$. A. (ed) : 16-18. Blackwell Scientific Publications.

HANSSON, L. A. (1988) : Effects of competitive interactions on the biomass development of planktonic and periphytic algae in lakes. Limnol. Oceanogr., $33: 121-128$.

Hansson, L. A. (1992) : Factors regulating periphytic algal biomass. Limnol. Oceanogr., $37: 322-328$.

HAWES, I. and A-M. SchwARZ (1996) : Epiphytes from a deep-water characean meadow in an oligotrophic New Zealand lake: species composition, biomass and photosynthesis. Freshwat. Biol., $36: 297-313$.

HiLl, W. R. and H. L. Boston (1991): Community development alters photosynthesis-irradiance relations in stream periphyton. Limnol. Oceanogr., 36: $1375-1389$.

Hirose, H. and T. Yamagishi (1977) : Illustrations of the Japanese fresh-water algae. Uchidarokakuho (in Japanese).

Hori, T., Y. Sugiyama, M. Kanao, M. Nagai, N. Taniguchi, M. Sugiyama, and T. FuJINAGA (1996) : Distribution of some chemical components in Lake Biwa under usual and unusual wet and drought conditions, 1992-1995. Jpn. J. Limnol., $57: 183-197$.

Jonsson, G. S. (1992) : Photosynthesis and production of epilithic algal communities in Thingvallavatn. Oikos, $64: 222-240$.

KALFF, J. and E. BenTZEN (1984) : A method for the analysis of total nitrogen in natural waters. Can. J. Fish. Aquat. Sci., $41: 815^{-819 .}$

Lorenz, R. C. and C. E. Herdendorf (1982) : Growth dynamics of Cladophora glomerata in western Lake Erie in relation to some environmental factors. $J$. Great Lake Res., $8: 42-53$.

LORENZEN, C. J. (1967) : Determination of chlorophyll and pheopigments spectrophotometric equation. Limnol. Oceanogr., $12: 343-346$.

Lowe, R. L. (1996) : Periphyton patterns in lakes. In Algal Ecology, Strevenson, J., Bothwell, M. L. and R. L. Lowe (eds) : 57-76. Academic Press.

Meulemans, J. T. (1988) : Seasonal changes in biomass and production of periphyton growing upon reed in Lake Maarsseveen I. Arch. Hydrobiol., $112: 21-42$.

Moss, B. (1988) : Ecology of Freshwaters (Man and Medium). Blackwell.

Müller, U. (1994) : Seasonal development of epiphytic algae on Phragmites australis (CAV.) Trin. ex STEN. in a eutrophic lake. Arch. Hydrobiol., 129 : 273-292.

MüLLER, U. (1995) : Vertical zonation and production rates of epiphytic algae on Phragmites australis. Freshwat. Biol., 34:69-80.

Murphy, J. and J. P. Riley (1962) : A modified single solution method for the determination of phosphate in natural waters. Anal. Chem. Acta., $27: 31-36$.

NAKANISHI, M. (1976) : Seasonal variations of chlorophyll $a$ amounts, photosynthesis and production rates of macro- and microphytoplankton in Shiozu bay, Lake Biwa. Physiol. Ecol. Japan, 17 : 535-549.

NaKanishi, M. and N. Yamamura (1984): Seasonal changes in the primary production and chlorophyll $a$ amount of sessile algal community in a small mountain stream, Chigonosawa. Mem. Fac. Sci., Kyoto Univ. Ser. B, $9: 41^{-}$ 55 . 
Nakanishi, M., C. Saraceni, and A. Kurata (1989) : Comparison of some limnological variables in the waters between the upper and lower littoral areas within an Egeria stand. Arch. Hydrobiol., 116 : 313-331.

Nakanishi, M., Y. Tezuka, T. Narita, O. Mitamura, K. Kawabata, and S. Nakano (1992) : Phytoplankton primary production and its fate in a pelagic area of Lake Biwa. Arch. Hydrobiol. Beih. Ergebn. Limnol., 35 : 47-67.

Nozaki, K., H. Mitsuhashi, and A. Tuji (1998): Preliminary report on diel changes of dissolved oxygen concentration in filamentous green algal mat at littoral zone of Lake Biwa. Jpn. J. Limnol., 59 : 207-213 (in Japanese with English abstract).

Pieczyńska, E., T. Ozimek, and J. I. Rybak (1988) : Long-term changes in littoral habitats and communities in Lake Mikolajskie (Poland). Int. Revue Ges. Hydrobiol., 73: 361-378.

Power, M. E. (1990a) : Effects of fish in river food webs. Science, $250: 411-415$.

Power, M. E. (1990b) : Benthic turfs vs floating mats of algae in river food webs. Oikos, $58: 67-79$.

Saijo, Y., M. Sakamoto, Y. Toyoda, H. Kadota, H. Miyoshi, S. Horie, H. KaWANABE, and M. Tsuda (1966) : Interim report of lake metabolism. Biwako Seibutsushigen Chosa-dan (BST) Chukan Hokoku. Osaka, Kensetsusho, Kinki Chiho Kensetsu-kyoku. 406-466 (in Japanese).

Solorzano, L. (1969) : Determination of ammonia in natural waters by the phenolhypochlorite method. Limnol. Oceanogr., 14: 799-801.

Steinman, A. D., R. Meeker, A. J. Rodusky, W. R. Davis, and C. D. Mclntire (1997) : Spatial and temporal distribution of algal biomass in a large, subtropical lake. Arch. Hydrobiol., $139: 29-50$.

STRICKLAND, J. D. H. (1958) : Solar radiation penetrating the ocean. A review of requirements, data and methods of measurement; with particular reference to photosynthetic productivity. J. Fish. Res. Bd. Canada, $15: 453-493$.

Takamura, N., T. Iwakuma, M. Aizaki, and M. Yasunơ (1990) : Primary production of epiphytic algae and phytoplankton in the littoral zone of Lake Kasumigaura. Marine Microbial Food Webs, 4 : 239-255.

Tezuka, Y. (1984) : Seasonal variations of dominant phytoplankton, chlorophyll $a$ and nutrient levels in the pelagic regions of Lake Biwa. Jpn. J. Limnol., $45: 26-37$.

Tezuka, Y. and M. NAKANishi (1991) : Relationship between water quality and phytoplankton in Lake Biwa. Ann. Rept. Interdiscipl. Res. Inst. Environ. Sci., $10: 43-57$ (in Japanese with English abstract).

TominaGa, H. and S. ICHImura (1966) : Ecological studies on the organic matter production in a mountain river ecosystem. Bot. Mag. Tokyo, 79 : 815-829.

Turner, M. A., E. T. Howell, G. G. C. Robinson, J. F. Brewster, L. J. Sigurdson, and D. L. Findlay (1995a) : Growth characteristics of bloomforming filamentous green algae in the littoral zone of an acid lake. Can. J. Fish. Aquat. Sci., 52 : 2251-2263.

Turner, M. A., G. G. C. Robinson, B. E. Townsend, B. J. Hann, and J. M. Amaral (1995b) : Ecological effects of blooms of filamentous green algae in the littoral zone of an acid lake. Can. J. Fish. Aquat. Sci., $52: 2264-2275$.

Watanabe, T. and A. Houki (1988) : Attached diatoms in Lake Biwa. Diatom, 4 : 21-46. 
Kentaro NozaKI : Center for Ecological Research, Kyoto University, Shimosakamoto Otsu 520-0105, Japan, Present address : Limnological Laboratory, School of Environmental Science, The University of Shiga Prefecture, 3615 Hassaka, Hikone 522-8533, Japan, (野崎健太郎： ₹ 520-0105 大津市下阪 本 4-1-23, 京都大学生態学研究センター, 現所属, ₹ 522-8533 彦根市八坂町 3165 , 滋賀県立大学環境科学部湖沼環境実験施設)

(Received : 28 April 1998 ; Accepted : 5 December 1998)

\title{
琵琶湖北湖沿岸の啋帯における藻類の群落構造
}

\author{
野崎健太郎
}

摘

要

琵琶湖北湖沿岸の碎曼において, 底生藻㧍よび浮遊藻群落の現存量と種組成の季節変動 を 1994 年 6 月から 1996 年 4 月にかけて調べた。現存量の大きな季節変動は, 底生藻群落 では系状緑藻 Spirogyra sp., 浮遊藻群落では Closterium aciculare, Staurastrum dorsidentiferum, Gomphosphaeria lacustrisの消長に起因していた。底生藻拈よび浮遊藻群落 の現存量の極大は，ともにわずか $1 \sim 2$ 種の優占的な增殖に由来していた。全藻類量に占め る底生藻群落の割合は，全ての調查地点で平均 $90 \%$ 以上であった。従って，本調查地では 底生藻が基礎生产者として卓越していると評洒された。湖沼沿岸带における藻類群落の基 礎生産構造は, 一般的に浮遊藻および底生藻群落から成る 2 層構造と見なされてきた。 Spirogyraの様な糸状緑藻も底生藻の 1 構成員とされてきたが, 基質への付着器を持なな いSpirogyraは, 石面上で固着生活する底生藻群落（固着藻群落）を覆うように繁茂し， また群落内の光の消散係数は両群落で著しく異なっていた。従って, 湖沼沿岸帯の藻類群 落の基礎生産構造は, 浮遊藻, 系状緑藻および固着藻群落から成る 3 層構造として捉える べきであると結論付けた。 